\title{
Translation and cross-cultural adaptation of "Hoja Verde de Salud Medioambiental Reproductiva" in Brazil
}

Suellen Dayse de Moura Ribeiro 1

Marília Teixeira de Siqueira 2

Clarice Umbelino de Freitas 3

Ana Laura Carneiro Gomes Ferreira 4

Ariani Impieri de Souza 5

1 Residência Multiprofissional de Saúde Coletiva. Faculdade de Ciências Médicas. Universidade de Pernambuco. Rua Arnóbio Marques, 310 . Santo Amaro. Recife, PE, Brasil. CEP: 50.100-130. E-mail: suellenribeiro.sr@gmail.com

2,3 Faculdade de Ciências Médicas. Universidade de Pernambuco. Recife, PE, Brasil

4,5 Instituto de Medicina Integral Prof. Fernando Figueira. Recife, PE, Brasil

\begin{abstract}
Objectives: to perform a cross-cultural adaptation of "Hoja Verde de Salud Medioambiental Reproductiva", originally conceived in Spanish for Brazilian Portuguese.

Methods: the translation and cross-cultural adaptation process was carried out in five stages: translation, synthesis of the versions, back-translation, the acquisition of a consensual version after reviewed by the committee specialists and the application of the pretest to obtain the final version. The interviews were carried out at two reference services in maternal and child health, both located in Recife, Pernambuco, which provided medical care for highrisk pregnancies with a diversified clientele regarding the region of the State.

Results: there were difficulties in understanding some words during the pretest and the precision of dates for medication use, radiation tests, as well as weeks of pregnancy and breastfeeding duration in weeks. The committee specialists made some alterations on the questionnaire considering suggestions made by the interviewees.

Conclusions: after the adaption process, an available instrument in detecting environmental risks which might be incorporated in the maternal and child health routines and could contribute in detecting and preventing diseases and the severities and promote health for Brazilian children.
\end{abstract}

Key words Cross-cultural comparison, Translation (Process), Environmental health, Reproductive health 


\section{Introduction}

In recent decades the relation between health and environment has been in evidence, since environmental damage threatens life support systems, including mankind and despite of scientific, materials and economic advances recently obtained, the consequences of this deterioration brought several impacts to human health. ${ }^{1}$ As a certain concern from various countries, this theme has been an issue of international agreements since the beginning of the $20^{\text {th }}$ century. ${ }^{2}$

The periods between the peri-conceptual and birth, as well as childhood, these represent stages of particular vulnerability to the environmental agents. The associations between environmental exposures such as air pollution, heavy metals, pesticides, the use of tobacco, alcohol and other drugs may lead to adverse outcomes, such as miscarriage, low birth weight, prematurity, fetal alcoholism syndrome, behavioral problems, reproductive health and among others. $3-7$

The embryo, fetus and children are particularly vulnerable to the environmental risk factors. ${ }^{8}$ The sooner the person is exposed to chemicals more likely s/he will develop health problems. 9 The degree and type of interaction with the environment varies according to age, socio-cultural patterns and places of residency, differentiating between urban and rural areas. 10

The environmental risk factors act together and the economic and social conditions enhance the adverse and its effects, especially in situations of conflict, poverty and malnutrition. Such factors determine health, quality of life, children's growth and development causing impacts on the health of adolescents and the future adults. ${ }^{8}$

The vulnerability of the children often depends on the development stage they are in, because there are some critical periods in the structural and functional development, both in pre and post-natal life, especially when a given structure or function is more sensitive to alterations. In addition, the children have a higher intestinal permeability and the immaturity of their detoxification system. ${ }^{11}$

According to the World Health Organization (WHO), recent knowledge about the special susceptibility of children to environmental risks should be used for structuring actions that ensure their growth and the development of good health. ${ }^{8}$ Besides the fact, children's environmental health is a recent theme, we are unaware of the existence of instruments prepared or adapted from other cultures for the Brazilian context is specifically the objective to detect early environmental risk factors on pregnant women, even in the peri-conceptional period, collaborating for the adoption of habits and healthy environments for children.

Among the advantages in achieving a crosscultural adaptation of instruments is the lowest cost, when compared to the preparation of new tests and the easiness to compare between the groups. 12 Although, there are several publications based on this theme, there is no consensus as to the forms of execution, making the operational synthesis a mosaic procedure from various sources. 13

The aim to promote learning and environmental health care, involving actors from different sectors and work fields, the Red Latinoamericana de Salud Ambiental Infantil (SAMBI), along with the professionals from Mount Sinai Hospital and the staff from a specialized unit in Environmental Pediatrics in Murcia, Spain created a project called "Salud Ambiental para el Embarazo, Lactancia y Crianza em Iberoamérica" (SAELCI).

SAELCI is a multicentric project. Its proposal is to promote child health care from the peri-conceptional up to childhood through the use of "Hoja Verde de Salud Medioambiental Reproductiva" as one more instrument in pre-natal consultations and/or puerperium, characterizing the parents' exposures to Latin America, Portugal and Spain. In Brazil, the study is being conducted only in the city of Recife.

\section{The Instrument}

The "Hoja Verde de Salud Medioambiental Reproductiva" was developed by a team from the Pediatric Environmental Health Specialty Unit (PEHSU) in Murcia, Spain, from the "Green Page" of WHO, an instrument which enables to identify and address the exposures of environmental risk for children. ${ }^{8}$ The new instrument is being used in Spain for a few years now and was adapted to be used during the period of pre-pregnancy, pregnancy and breastfeeding by professionals who dedicated themselves in the pediatrics environment collaborating with prevention, detection and treatment for diseases and severities.

A semi-structured questionnaire was elaborated and easy to apply, which assists in detection, prevention, reduction and/or elimination of environmental risk factors that exist since the period of periconceptional until childhood, seeking to contribute for the creation of healthier environments for children. The search gives subsidies for the diagnosis of exposure to the environmental risk factors, not 
counting on the scores, only one item aims to quantify the consumption of alcohol in the peri-conceptional period of both parents and then the mother during the pregnancy.

This questionnaire can be applied by any health professional member of the team involved in child care and pregnant women and/or postpartum in favor of the integral pregnancy approach and child's healthcare. ${ }^{14}$ The father is invited to participate of the interview as an fundamental actor for the mother and baby's health and to detect factor exposure in the peri-conceptional period. The application of the instrument represents an opportunity for the parents' guidance.

The questionnaire is composed of questions divided into nine blocks, to: a) The child parent's identification data (age and schooling), the date of the last menstruation, the family's monthly income, and among others; b) Reproductive obstetric history (including the occurrence of abortions and/or malformations, breastfeeding period, performed fertility treatment, contraceptive use); c) Exposure to ionizing radiation; d) Exposure to medication, including homeopathy and/or the consume of vitamin supplements; e) Occupational and leisure activities exposures; f) Consumption of tobacco and other drugs; g) Exposure to alcohol; h) Exposures to in or outdoor environments and i) Perception of environmental risk of parents in the household and/or community.

The objective of this study is to perform the cross-cultural adaptation of the Spanish language to Portuguese in Brazil of "Hoja Verde de Salud Medioambiental Reproductiva", based from the methodological steps required.

\section{Methods}

\section{The process of translation and cross-cultural adaptation}

The process of translation and cross-cultural adaptation was performed in five stages: translation, synthesis of the versions, back-translation, the acquisition of a consensual version after reviewed by the committee specialists and the application of the pretest to obtain the final version. ${ }^{15-19}$

Initially, two independent translations were made of the spanish language to the portuguese language. The first translation was performed by two health professionals with experience in public health and environmental health were aware of the purpose of this research and had fluency of the spanish language. The second translation was carried out by a sworn translator without previous contact with the instrument and was not aware of the purposes of this research and had no connection with the health area. ${ }^{16}$

All the translators involved in this first stage have the mother tongue as the target language Portuguese. 15,16 In both of the translations were emphasized the necessity of semantic equivalence of the items and not only literal. The two versions of the translation were compared by researchers and after elaborated one single version.

Then, two back-translations of the questionnaires were obtained which consisted in the translation back to the original language which enables to identify incorrect interpretations and failures of cultural adaptation contexts. 20 This was performed by two teachers of the Spanish language without any knowledge about the purpose of this research and without any prior contact with the original instrument and no involvement in the health area.

The formation of the committee specialists was proceeded, composed by two medical hygiene physicians, one of them was fluent in Spanish, two gynecologists and a professional specialist in fetal medicine, who analyzed the translated versions and the back-translation, seeking for the semantic equivalence (the translated words should contain the same meaning), idiomatic equivalence (certain expressions are difficult to translate to the another language, being able to elaborate new expressions when necessary), equivalence of experience (the questions could be able to capture the daily routine experience which could be measured in different ways when compared to different cultural contexts) and conceptual equivalence (the concept of words should be preserved seeking for words and phrases that could be represented between cultures). 16

A consensus version was elaborated (pre-final) which was forwarded to two specialized authors in environmental health who participated in the elaboration of the original version along with the professionals in Murcia, Spain. After clarifying doubts regarding some issues, an agreement was obtained by both. The questionnaire is accompanied in the manual.

\section{Application of the pre-test}

After a favorable statement from the Ethics Committee in Research at Hospital Universitário Oswaldo Cruz (CEP/HUOC) (CAAE number: 50091115.9.3002.5191) and the acceptance statement signed on the informed consent form and the approval consent for children under 18 years of age 
according to the Resolution 466/2012, the pre-test was applied for 30 participants from the two services, both are located in the city of Recife, Pernambuco. These services provide medical care to high-risk pregnancies and receive a diversified clientele regarding the region of the State: The Centro Integrado Professor Amaury de Medeiros (CISAM), from the Universidade de Pernambuco, and Instituto de Medicina Integral Prof. Fernando Figueira (IMIP). In each health unit 15 women, pregnant women (25) or postpartum (5) were interviewed in October, 2015. Pregnant women at any gestational age and postpartum, in immediate or delayed periods, accompanied with someone, if under aged, parents or guardians allowed them to participate were included in the study. The exclusion criterion was for those who did not have mental conditions to answer the questions. The interviews were conducted by the first researcher and by five medical students from the Universidade de Pernambuco and the Faculdade Pernambucana de Saúde, after being trained for data collection.

During the pre-test, the participants of this study identified difficult expressions to understand. For these questions, suggestions were requested to replace the expressions or an inclusion of explanatory terms which allowed the participant to require a better understanding of the question demanded.

\section{Results}

In the phase of the pre-test, the interview ranged between 20 and 25 minutes. The group was comprised of residents from 10 towns in Pernambuco, mainly the towns of Recife (33.3\%), Olinda (30.0\%) and Jaboatão dos Guararapes $(13.3 \%)$ and only one pregnant woman lived in the rural area. The age ranged from 15 to 39 years with a mean of 20.5 years. The schooling levels varied from not have gone to school to undergraduates, although half of them graduated from high school. Only $23.3 \%$ reported being white colored skin, while $60.0 \%$ recognized to be mixed color. The age of the babies' parents ranged from 17 to 54 years and 50\% of them graduated from high school. $53.3 \%$ of the monthly income was up to two minimum wages (R\$ 788.00 was the minimum wage at the period of the interviews, equivalent to US\$203.15). The gestational age ranged from 17 to 39 weeks.

There were difficulties in understanding certain expressions. In block B (obstetric history), the term hormonal contraceptives use, and in block $\mathrm{C}$ (ionizing radiation), the term ionizing radiation was not understood by all participants. In addition, the pregnant and postpartum women could not explain the dates in taking medications, reporting to be quite difficult to specify the initial date and the end, and radiation exams, as well as weeks of gestation and duration of breastfeeding in weeks. On these occasions the prenatal card was requested.

After another meeting with the committee of specialists, taking into consideration the participants' suggestions, small alterations were made in the questionnaire, as for example: in parentheses were added the words "pills, injection" to facilitate the understanding of hormonal contraceptive use, as well as the colloquial expression "X-Ray" to understand the term in ionizing radiation. In block $\mathrm{B}$, the period of breastfeeding was obtained in months and not weeks. The initial date and the end of taking medication were modified for the periods between one month before the gestation, the trimesters of pregnancy and the breastfeeding period. In block E, the words "aeromodeling" (aeromodelismo in Portuguese) and "maqueación" (making of models, design) were withdrawn from the activities for not relating to Brazilian usual activities. The main alterations can be seen in Table 1 .

During the interviews, when the baby's father was not present, the mother had some difficulty to answer about the father's tobacco and alcohol consumption, regarding to specific issues relating to the period of spermatogenesis, as for example: "How much did you smoke before getting pregnant?" (how many cigarettes/a day)?, "How old were you when you started smoking?", "how much do you smoke now (how many cigarettes/a day)?", alcohol intake (in grams/a day) in the two months prior to getting pregnant. The difficulties occurred due to the fear on the behalf of some not responding the question precisely or due to the short time of their relationship or even the absence of the father during the pregnancy. In these cases it was encouraged to relate celebration dates and festivity periods, to emphasize the period of peri-conceptional to base on the date of the last menstruation (DUM) or on the first ultrasound which this one facilitated the answer.

The following questions were also added: "The baby's father had exams with exposure of ionizing radiation ("X-Ray") up to two months prior the date of the last menstruation (DUM)?" in block C, the question is just for the baby's mother; "Do you or someone who lives with you work with agriculture?"; "If yes, do you store pesticides at home? Where?", "Do you reuse the packaging of pesticides to store food or water?", "Do you dye and/or straighten your hair or on somebody's else?", in block E; "Did you recently reform or paint your 
house?", and, "Did you receive a visit from an agent of the environmental health at your home for mosquito control? If yes, where? At home, the water well or on the street?" this was in block H. In addition, a new block of questions were elaborated about concept data (block J), which discusses: gestational age and birth weight, head circumference, gender, mother's comorbidities during pregnancy and so on. The authors of the original version were consulted, as mentioned before, they also agreed with the additional, since the issues are closely related to the aim of the questionnaire, environmental risk factors rather are quiet present in the Brazilian context and the unusual scenario at the time in the country - the identification of Zika virus and its probable relation to microcephaly with the largest number of cases registered in the city of Recife.

The main environmental exposures are described in Table 2, where it can be observed the high frequency of alcohol consumption, exposure to chemicals substances and 1 case of ionizing radiation exposure.

\section{Discussion}

A careful implementation of each stage was performed for the cross-cultural adaptation of the instrument and included some words for a better understanding for the main public and issues related to the Brazilian reality. CISAM and IMIP are references for the care provided to high-risk pregnancy attending a quite diversified demand from several towns in Pernambuco State, which collaborated for the heterogeneity of participants, as for example, in relation to schooling, family monthly income, gestational age, reproductive obstetric history and environmental exposures.

The cross-cultural adaptation of the instrument requires a thorough process. The translation is the first step in trying to obtain concepts, words and expressions that are cultural, psychological and linguistically equivalent in a second language and culture. ${ }^{12}$ Although there is no consensus in the literature about the adaptation of instruments, the suggested steps were already accomplished and/or carried out by some authors. $16-18,21$

The use of two translations was important because it was allowed to compare and discuss in the elaboration of the synthetic version, making the conceptual translation easier and ensuring to eliminate errors and ambiguous interpretations. 21,22 One of the translations, following the other authors' recommendations, was performed by a professional without any knowledge about the purpose of this research and without any link regarding to the health sector, as the translator was "naive", s/he would be more apt to identify different meanings comparing to the original ones, in this case, as the first translators. 15,16

The use of two translations and two back-translations is regarded as the minimum necessity to detect difficulties, minimizing possible errors and promoting the achievement of the versions with semantic, idiomatic, experiential or cultural and conceptual equivalences. Following recommendations, the two back-translators were not aware about the concepts explored and the purpose of this study, without any clinical "connection", which increases the probability to highlight discrepancies. 16

Unlike other studies, the characteristics of the original instrument hinders the adaptation to Portuguese, the translation on labor activities and different probabilities of environmental exposure, for example, this was elaborated without any difficulties for Brazilian experiences. 23 There was no necessity of replacing words, only removing words such as "aeromodelismo" and "maquetación" for not representing work activities or leisure which usually are present in the Brazilian context, the other options were remained.

At all time, there was a concern about using an easier form of the language to be understood, which would make the survey much easier to achieve by using the instrument. One of the alterations was to understand the period of taking medication, which was modified to facilitate the identification of the baby's exposure from the gestational period, since the effects on the fetus depends among other aspects, such as the time of the exposure during the pregnancy. In addition, the scope of various schooling levels of the interviewed population probably enables the use of the questionnaire for the pregnant and postpartum women in Brazil at any schooling level. 21

The application of the questionnaire "Green Page of Environmental Reproductive Health" at referential services for high-risk pregnancy can be considered a limiting factor, since the population that quest for these health units, do not represent the actual situation of the exposed population in general. However, the reference service provides greater diversity and frequency of risky situations, which allows a better judgment of understanding the data collection instrument for its adaptation, which is the goal of this study.

The alterations made in the original instrument were taken in consideration life habits and Brazilian environmental exposures with a narrow relation to 


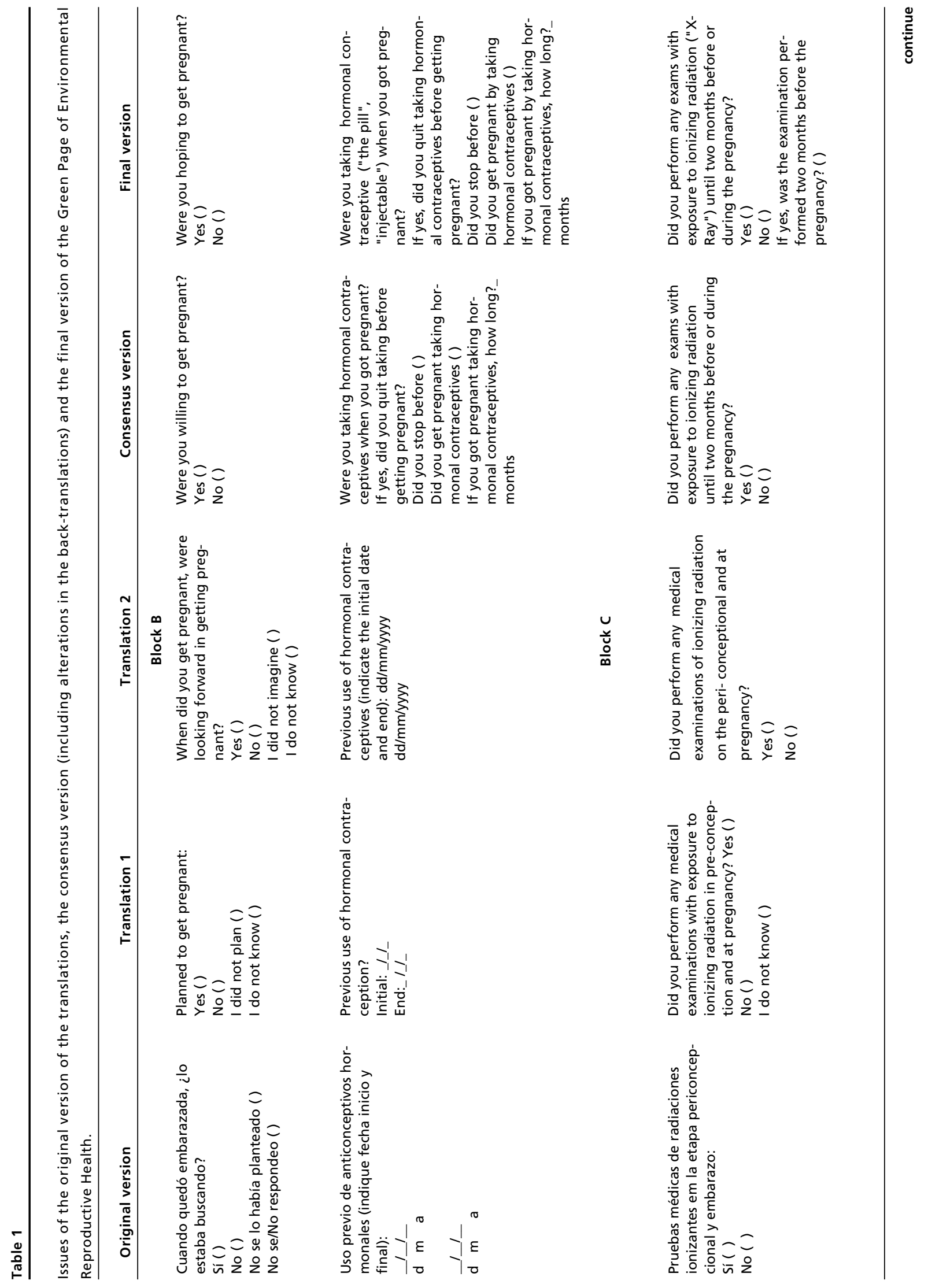




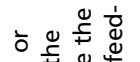

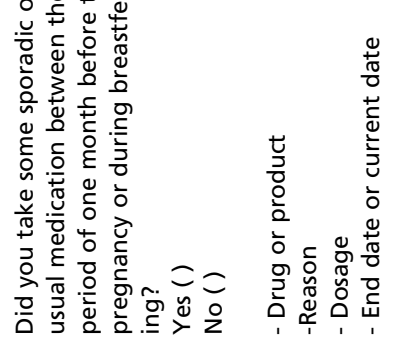

\section{달}

离亭

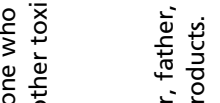

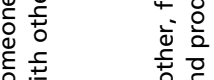

起

立辛

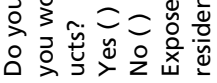

อั

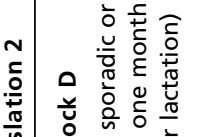

응

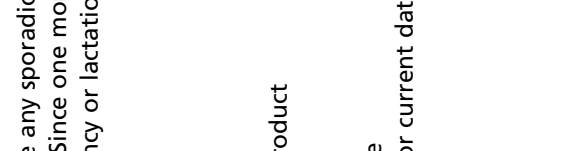

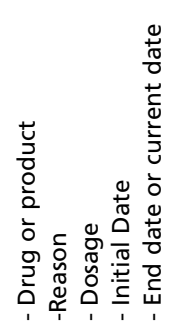

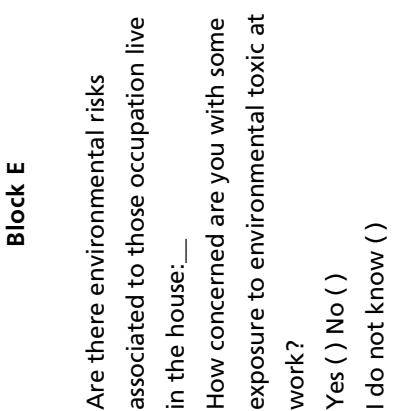

כ)

동ำ

ํํำ

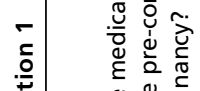

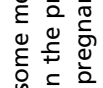

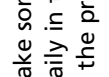

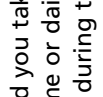

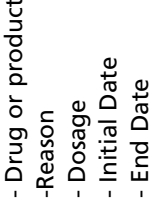

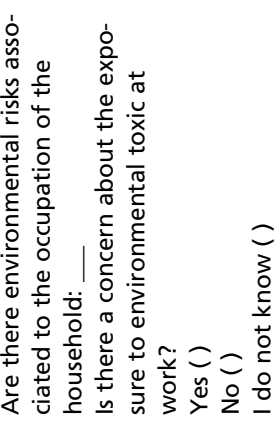

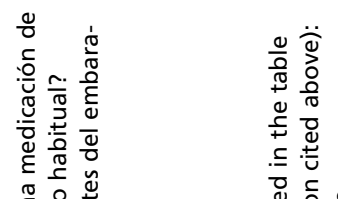

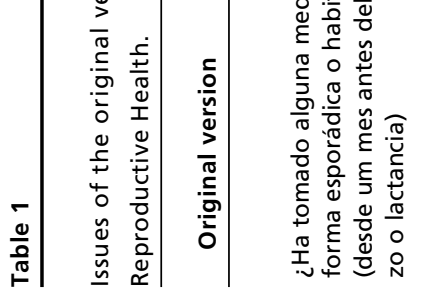

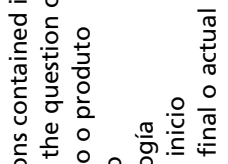

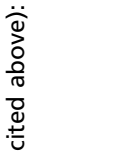

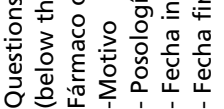

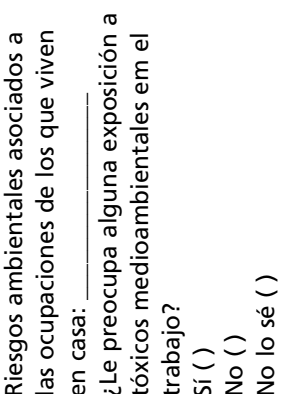


Exposure of pregnant and postpartum women to environmental risk factors detected through the "Green Page of Environmental Reproductive Health". Recife, 2016.

\begin{tabular}{|c|c|c|}
\hline Variable & $\mathbf{N}$ & $\%$ \\
\hline Contraceptive use & 3 & 10.0 \\
\hline Exposure to ionizing radiation & 1 & 3.3 \\
\hline Use of medication & 30 & 100.0 \\
\hline Living with someone who works with toxic products & 8 & 26.7 \\
\hline Working with toxic products (bleach, disinfectant, formaldehyde etc) & 3 & 10.0 \\
\hline Perform or live with someone who performs activities, as leisure exposures to chemical substance & 3 & 10.0 \\
\hline Dye and/or straighten your own hair or someone else & 8 & 26.7 \\
\hline Use of tobacco & 3 & 10.0 \\
\hline Passive exposure to tobacco smoke & 14 & 46.7 \\
\hline Exposure to other drugs (active or passive) & 3 & 10.0 \\
\hline Alcohol consumption (peri-conceptional period) & 17 & 56.7 \\
\hline Alcohol consumption during pregnancy & 4 & 13.3 \\
\hline Perform recent reform or painting of the homes & 16 & 53.3 \\
\hline Problems with ants, mosquitoes, cockroaches, rodents & 29 & 96.7 \\
\hline The use of pesticides (powder, aerosol, plug-ins) & 21 & 70.0 \\
\hline Visit by an agent of the environmental health for mosquito control & 11 & 36.7 \\
\hline Use of biological larvicide by an agent of the environmental health & 9 & 30.0 \\
\hline Environmental Concern (accumulation of garbage, mosquitoes, "zika virus", among others) & 15 & 50.0 \\
\hline
\end{tabular}

the purpose of this research. Screening instruments in the environmental health, during this period of life, were never adapted to the Brazilian context, representing a singular opportunity for a greater insertion of the theme and the importance in addition to the advantage mentioned by some authors, comparing distinct population groups. 12

A recent study on head circumference at birth and the exposure to tobacco, alcohol and illegal drugs in early pregnancy, illustrates well the use and its potential "Green Page of Environmental Reproductive Health" for pregnant women. In the study, alcohol consumption, even in low doses, and exposure of ionizing radiation were related to lower head circumference of the babies. Around $13.0 \%$ of the pregnant women reported illegal drugs consumption. According to the authors, these findings reinforce the need of counseling and guidance of the parents to assume a more preventive measurement for the fetus and newborn, which could be performed by applying the questionnaire. 24 In this present study, 17 interviewees (56.7\%) consumed alcohol during the peri-conceptual period and $4(13.3 \%)$ during pregnancy, $3(10.0 \%)$ reported tobacco use and 3 reported exposure to illicit drugs, as well as passive exposure to tobacco, the use of pesticides, among other important exposures (Table 2).

After completing the stages recommended in the literature, "Green Page of Environmental Reproductive Health" could be applied on a larger scale, giving subsidies to the knowledge of the situation exposed to environmental risk factors in our cultural context, as well as serve as an instrument to evaluate possible adverse effects in the concepts. To the extent that this instrument identifies risk factors, it is always subjected to change and become improved, by accompanying our reality of exposure. Then, the available instrument detects the environmental risks, which may be incorporated in the actions of the maternal and child health routine, contributing to detect and prevent diseases, severities and health problems and promote health for Brazilian children. The instrument will also be allowed to compare the environmental exposures between different socio-cultural contexts, as the participating countries in the SAELCI project.

\section{Acknowledgements}

We would like to thank Rosa Gabriela Roriz and Bianca Távora for their collaboration in the data collection, and Mariana Távora for collecting and coding the data and the partnership of Izadora Karina da Silva and Marianna Rachel Nunes Marques during the data collecting, coding and reviewing the data. 


\section{References}

1. Freitas CM, Porto MF. Saúde, ambiente e sustentabilidade [online]. Rio de Janeiro: Editora FIOCRUZ, 2006 Disponível em: https://books.google.com.br/books?hl= ptBR\&lr $=\& \mathrm{id}=\mathrm{H}$ kIqBQAAQBAJ\&oi $=$ fnd $\& p g=$ PA4\&ots $=$ qULVz8ywSy\&sig=jJXQ1TMy9oypPCw2brtuudVX24\&re dir_esc $=\mathrm{y} \# \mathrm{v}=$ onepage $\& \mathrm{q} \& \mathrm{f}=$ false.

2. Brasil. Ministério da Saúde. Subsídios para construção da Política Nacional de Saúde Ambiental [online]. Brasília: Editora do Ministério da Saúde, 2007. Disponível em: http://conselho.saude.gov.br/biblioteca/livros/subsi miolo. pdf.

3. Souza MCB, Mancebo ACA, Santos HCN, Costa ALR, Taitson PF, Moreira MFR. Fatores ambientais e reprodução: metais (chumbo e cádmio). Fundamentação da pesquisa JBRA Assist Reprod. 2010; 14 (4): 38-42.

4. Twardella D, Bolte G, Fromme H, Wildner M, Von Kries R and the GME Study Group. Exposure to secondhand tobacco smoke and child behaviour - results from a crosssectional study among preschool children in Bavaria. Acta Paediatrica [periódico online]. 2010 [acesso em $20 \mathrm{fev}$ 2016]. $99 \quad$ (1): $6 \mathrm{p}$. Disponível em http://onlinelibrary.wiley.com/doi/10.1111/j.16512227.2009.01522.x/epdf

5. Costa TS, Vasconcelos TC, Sousa LB, Bezerra CP, Miranda FAN, Alves SGS. Percepções de adolescentes grávidas acerca do consumo de álcool durante o período gestacional SMAD, Rev Eletrônica Saúde Mental Álcool Drog 2010 [acesso em 10 mar. 2016]. 6 (1): 1-15. Disponível em http://pepsic.bvsalud.org/pdf/smad/v6n1/03.pdf.

6. Arbex MA, Santos UP, Martins LC, Saldiva PHN, Pereira LAA, Braga ALF. A poluição do ar e o sistema respiratório. J Bras Pneumol [periódico online]. 2012 [acesso em 4 jan 2016]. 38: 13p. Disponível em: http://www.scielo.br/pdf/ jbpneu/v38n5/v38n5a15.pdf.

7. Mendonça GR1, Bueno PC, Apgáua G, Lima G, Martelli ME, Luvizotto MJ. O impacto do consumo de agrotóxicos na prevalência de desfechos perinatais no Brasil. Bol Mal Salud Amb [periódico online]. 2014 [Acesso em: 06 jan. 2016]. 54: 7p. Disponível em: http://www.scielo.org.ve/pdf/ bmsa/v54n1/art09.pdf.

8. WHO (World Health Organization). Guide and instructions for the implementation of the Green Page. Green Page Children's Environmental History. 2006. Disponível em: http://www.who.int/ceh/capacity/greenpageguidelinesmarch2007.pdf.

9. Landrigan PJ, Goldman LR. Children's Vulnerability to Toxic Chemicals: a Challenge and Opportunity to Strengthen Healthand Environmental Policy. Health Affairs [periódico online]. 2011 [acesso em $10 \mathrm{fev}$ 2016]. 30: 9p. Disponível em: http://content.healthaffairs.org/content/ 30/5/842.full.pdf + html

10. Mazoto ML, Filhote MIF, Câmara VM, Asmus CIRF. Saúde Ambiental Infantil: Uma revisão de propostas e perspectivas. Cad Saúde Coletiva [periódico online]. 2011 [acesso em 11 fev 2016]. 19: 10p. Disponível em: http://www.cadernos.iesc.ufrj.br/ cadernos/images/csc/2011 1/artigos/CSC v19n1 4150.pdf.
11. Agency for Toxic Substances and Disease Registry ATSDR. Toxicological profile for Endosulfan, 2013. [Acesso em: 27 set. 2015]. Disponível em: $<$ www.atsdr.cdc.gov/toxprofiles/tp41.html>.

12. Hambleton RK. Issues, designs, and technical guidelines for adapting tests into multiple languages and cultures. In: Hambleton RK, Merenda PF, CD Spielberger, editores. Adapting educational and psychological tests for crosscultural assessment. New Jersey: Lawrence Erlbaum; 2005. p. 33-8.

13. Reichenheim ME, Morais CL. Operacionalização de adaptação transcultural de instrumentos de aferição usados em epidemiologia. Rev Saúde Pública [periódico online]. 2007 [acesso em 17 fev 2016]. 41: 9p. Disponível em: http://www.scielo.br/pdf/rsp/v41n4/en_6294.pdf.

14. Sánchez Sauco MF, Jaimes Vega DC, Ortega García JA, Esquerdo Laib M, Jiménez Roset J. La hoja verde como una herramienta clínica para el tamizaje de factores de riesgo ambientales em la consulta prenatal. Rev Salud Ambient. 2013; 13(Espec Congr): 83-151.

15. Guillemin F, Bombardier C, Beaton D. Cross-cultural adaptation of health-related quality of life measures: literature review and proposed guidelines. J Clin Epidemiol. 1993; 46 (12): 1417-32.

16. Beaton DE, Bombardier C, Guillemin F, \& Ferraz MB. Guidelines for the process of cross cultural adaptation of self-report measures. Spine. 2000; 25 (24): 3186-91.

17. Vilete L, Figueira I, Coutinho E. Adaptação transcultural para o português do Social PhobiaInventory (SPIN) para utilização entre estudantes adolescentes. Rev Psiquiatr RS. 2006; 28 (1): 40-8.

18. Guimarães RP, Alves DPL, Silva GB, Bittar ST, Ono NK, Honda E, et al.Tradução e adaptação transcultural do instrumento de avaliação do quadril "Harris Hip Score". Acta Ortop Bras. [periódico online]. 2010 [Acesso em: $02 \mathrm{fev}$. 2016]. 18: 6p. Disponível em: http://www.scielo.br/pdf/ aob/v18n3/05.pdf.

19. Giusti E, Befi-Lopes DM. Tradução e adaptação transcultural de instrumentos estrangeiros para o Português Brasileiro (PB). Pró-Fono Revista de Atualização Científica. [periódico online]. 2008 [acesso em 5 fev 2016]. 20 (3): 4p. Disponível em: http://www.scielo.br/pdf/ pfono/v20n3/12.pdf.

20. Siqueira TF, Colares V, Ximenes R. Questionário sobre padrões de peso e alimentação para adolescentes (QEWPA): avaliação transcultural e adaptação para o Português. Adolesc Saude. 2015; 12 (2): 29-41.

21. Rocha RS, Bezerra SC, Lima JWO, Costa FS. Consumo de medicamentos, álcool e fumo na gestação e avaliação dos riscos teratogênicos. Rev Gaúcha Enferm. [periódico online]. 2013 [acesso em 6 fev 2016]. 34 (2): 9p. Disponível em: http://www.scielo.br/pdf/rgenf/v34n2/ v34n2a05.pdf.

22. Sardinha A, Levitan MN, Lopes FL, Perna G, Esquivel G, Griez E, et al. Tradução e adaptação transcultural do Questionário de Atividade Física Habitual. Rev Psiq Clín. [periódico online]. 2010 [acesso em 10 mar 16]. 37 (1): 7p. 
Disponível em: http://www.scielo.br/pdf/rpc/v37n1/ a04v37n1.pdf.

23. Miura CTP, Gallani MCBJ, Domingues GBL, Rodrigues RCM, Stoller JK. Adaptação cultural e análise da confiabilidade do instrumento Modified Dyspnea Index para a cultura brasileira. Rev Latino-Am Enfermagem [periódico online]. 2010 [acesso em 6 jan 2016]. 18 (5): 11p. Disponível em: http://www.scielo.br/pdf/rlae/v18n5/ pt 25.pdf.
24. Ortega-García JA, Gutierrez-Churango JE, Sánchez-Sauco MF, Martínez-Aroca M, Delgado-Marín JL, Sánchez-Solis $\mathrm{M}$, et al. Head circumference at birth and exposure to tobacco, alcohol and illegal drugs during early pregnancy. Childs Nerv Syst [periódico online]. 2012 [acesso em 3 abr 2016]. 28: 7p. Disponível em: http://link.springer.com/article/10.1007\%2Fs00381-0111607-6.

Received on May 6, 2016

Final version presented on October 7, 2016

Approved on October 20, 2016 